\title{
Country-of-Origin and Industry FDI Agglomeration of Foreign Investors in an Emerging Economy
}

\author{
Danchi Tan \\ Department of International Business \\ National Chengchi University \\ 64, Chih-Nan Rd. Sec. 2, Taipei, 116 \\ Taiwan \\ Tel: +886 $22939-3091$ ext. 81139 \\ Fax: +886 2 2938-8636 \\ dctan@nccu.edu.tw \\ Klaus E. Meyer \\ School of Management \\ University of Bath \\ Claverton Down, Bath, BA2 7AY \\ United Kingdom \\ Tel: +44 1225383695 \\ k.meyer@bath.ac.uk \\ www.klausmeyer.co.uk \\ Forthcoming in: Journal of International Business Studies \\ 2011 \\ Acknowledgements: The authors wish to thank Hung Vo Nguyen for permission to use the data from \\ Meyer and Nguyen (2005), and Tina Pedersen for her detailed editorial comments. Moreover we thank \\ many of our colleagues, including conference participants at the AIB in San Diego for helpful comments
} on earlier drafts of this paper. 


\title{
Country-of-Origin and Industry FDI Agglomeration of Foreign Investors in an Emerging Economy
}

\begin{abstract}
Foreign investors access local knowledge by co-locating with other foreign direct investment (FDI) firms. However, different aspects of local knowledge can be obtained from different local businesses. Thus, some foreign investors co-locate with FDI firms from the same country of origin, while others co-locate with foreign industry peers. We argue that, relative to industry FDI agglomeration, country-of-origin agglomeration provides an effective channel for the sharing of sensitive and tacit knowledge about local business environments. Therefore, foreign investors in need of such local knowledge are more likely to locate in country-of-origin agglomerations. Empirical evidence based on FDI in Vietnam indicates that foreign investors who perceive local institutions as particularly weak and those with a high degree of outsidership in the local environment are more likely to seek country-of-origin agglomerations than industry FDI agglomerations.
\end{abstract}

Keywords: Location of FDI, country-of-origin agglomeration, industry FDI agglomeration, local knowledge, Vietnam 


\section{Introduction}

Investors entering a foreign market face a competitive disadvantage arising from their lack of knowledge of that market (e.g., Johanson \& Vahlne, 1977; Luo \& Peng, 1999). Access to local knowledge, therefore, is a key consideration in foreign entry strategies. One way of accessing local knowledge is to locate geographically close to firms holding such knowledge such as other FDI firms (firms in which a foreign entity holds a strategic equity stake). Hence, foreign investors often locate near other FDI firms in the same industry (industry FDI agglomeration) or near other FDI firms with the same country of origin (country-of-origin FDI agglomeration) (e.g., Chang \& Park, 2005; Chung \& Alcácer, 2002; Head \& Ries, 1996; Head, Ries \& Swenson, 1995; Nachum \& Wymbs, 2005; Shaver \& Flyer, 2000). These two forms of agglomeration differ in terms of their attractions. In this paper, we explore the conditions under which foreign investors tap into country-of-origin agglomerations in search of local knowledge and resources, and how country-of-origin agglomeration differs from industry FDI agglomeration.

As the agglomeration economics literature (Marshall, 1920; Krugman, 1991) has traditionally focused on industry agglomeration, the interdependence of location decisions by foreign investors is not well understood. Hence, we know relatively little of the determinants of country-of-origin FDI agglomeration, which gives rise to the following question: which foreign investors are likely to co-locate with FDI firms with the same country of origin rather than with foreign industry peers and under what circumstances? We therefore explore the differences in the drivers of these two patterns of FDI agglomeration.

Furthermore, co-location is not the only way for foreign investors to tap into local knowledge. For instance, a joint venture (JV) with local partners may help a firm obtain the knowledge held by local firms (Meyer, Wright \& Pruthi, 2009b). Thus, location decisions are 
part of a broader set of decisions on how to enter a country, which includes the choice of entry mode (McCann \& Folta, 2008). In this paper, therefore, we explore the rarely studied interdependence between location and entry mode, and propose that co-location and joint ventures are substitute means for gaining access to local knowledge. ${ }^{1}$

We argue that country-of-origin agglomeration is an important source of local knowledge for foreign investors who have a high degree of outsidership in the local context and for foreign investors who perceive local institutions as particularly weak. The knowledge sought by these foreign investors often concerns sensitive cultural and institutional aspects of the host economy. Such knowledge is typically tacit and can best be exchanged in relationships of mutual trust, which often develop in expat networks (Dhanaraj, Lyles, Steensma \& Tihanyi, 2004; Miller et al., 2008; Tung, 1998). As investors with a high degree of outsidership in the local context are likely to find it difficult to develop trust with local business partners (Tsui-Auch \& Möllering, 2010), we expect them to be more likely to tap into expat networks and, thus, favor country-of-origin agglomerations rather than industry FDI agglomerations. Moreover, inter-firm transactions rely more on trust when the local institutional frameworks provides only weak protection for market transactions and information exchange among strangers. Therefore, we argue that investors who perceive local institutions as weak are more likely to seek local knowledge from country-of-origin agglomerations.

Foreign investors' need for local knowledge is particular acute in emerging economies where institutions are often opaque and continuously changing. These business environments are, therefore, difficult for outsiders to access (Wright et al., 2005; Meyer et al., 2009a). For this

\footnotetext{
${ }^{1}$ Exceptions are the studies by Filatotchev, Strange, Piesse and Lien $(2007,2009)$, which find that an investor's equity share in its overseas affiliate increases with its economic and cultural links with the affiliate's location. Another exception is found in Meyer and Nguyen (2005), who show that an investor's use of the greenfield entry mode increases with the development of market-supporting institutions in a local market.
} 
study, we chose a country in which these conditions are evident: Vietnam. Vietnam is characterized by a diverse economic geography with multiple hubs of economic activity. Its relatively recent opening to FDI allows to study of the full stock of FDI, while the structure of provinces (58 units for statistical data) allows for detailed analysis of location patterns. The empirical evidence supports our theoretical arguments.

\section{Accessing Knowledge through FDI Agglomerations}

Foreign investors need local knowledge, especially in emerging economies (Anand \& Delios, 2002; Meyer et al., 2009b). One particular obstacle to the sharing of local knowledge is its tacit nature (Polanyi, 1962) - it is widely available but only embodied in people. It often has no codified form, as credible sources of information may not exist (Lord \& Ranft, 2000). The ability to exchange such tacit knowledge depends, to a large extent, on the quality of the relationship between the two organizations because successful exchange requires two-way communication between the individuals possessing and receiving the knowledge (Dhanaraj et al., 2004; Hansen, 1999).

In the context of an agglomeration, a high level of trust between firms facilitates knowledge transfer by reducing the costs associated with searching for information (Hansen \& Løvas; 2004), and by enabling frequent interactions and efficient communication between the firms (Pérez-Nordtvedt, Kedia, Datta \& Rasheed, 2008). Moreover, good relationships among the firms within an agglomeration allow for the establishment of feedback mechanisms, which improve the comprehension and assimilation of tacit knowledge. A high level of trust also reduces a firm's concern that other firms will take advantage of its weaknesses and expropriate its knowledge (Steensma \& Lyles, 2000; Tsui-Auch \& Möllering, 2010), 
Co-location with existing foreign entrants creates opportunities to develop relationships with others willing to share relevant local knowledge (Mitchell et al., 1994; Shaver et al., 1997). While foreign investors may also learn from indigenous firms, knowledge spillovers from prior foreign entrants tend to be more useful because they "have different backgrounds and face different operational difficulties from domestic competitors" (Shaver et al., 1997:813). In other words, co-location with other foreign entrants provides knowledge that can enable a new foreign entrant to overcome the liability of outsidership (Johanson and Vahlne, 2009). ${ }^{2}$

This study compares industry FDI agglomerations and country-of-origin agglomerations as sources of local knowledge in an emerging economy. Specifically, to gain access to local knowledge, foreign investors can locate in areas with a strong presence of other FDI firms in the same industry and/or of other FDI firms with the same country of origin. The agglomeration literature has extensively discussed industry agglomeration (e.g., Head \& Ries, 1996; Wei et al. 1999), while research on country-of-origin agglomeration is scarce (e.g., Chung \& Song, 2004; Shaver \& Flyer, 2000). We review the theoretical arguments concerning these types of agglomeration and then extend them to demonstrate how they differ in attracting investors.

\section{Industry FDI Agglomeration}

By co-locating with other foreign firms in the same industry, foreign entrants can gain access to local, industry-specific knowledge such as industrial forecasts, and information on local customer and supplier behaviors (Mariotti \& Piscitello, 1995). Such knowledge is often tacit and its transfer requires personal interaction (Polanyi, 1962). Geographic proximity facilitates the exchange of such knowledge because it enables frequent social and professional interaction among people from different companies and organizations within business and non-business

\footnotetext{
${ }^{2}$ In emerging economies, indigenous firms are less likely to be major sources of local knowledge for foreign investors because they are typically technologically backward. In some cases, foreign investors entering emerging economies may deliberately avoid locating near indigenous firms to avoid knowledge leakage.
} 
communities (Pouder \& St. John, 1996). For example, engineers working for different companies in the same industry often meet on social occasions and share industry-specific information, such as problem-solving knowledge (Almeida \& Kogut, 1997; Saxenian, 1994). Employee participation in these local networks enables firms to follow trends in markets and technologies (Porter, 1998), to reduce the time that managers spend searching for information (Almeida \& Kogut, 1997; Mariotti \& Piscitello, 1995) and to quickly react to competitors' moves.

Moreover, co-location within the same industry provides access to industry-specific resources, such as specialized labor and suppliers (Marshall, 1920; Krugman, 1991). As an agglomeration grows, the pool of specialized labor and suppliers expands, reducing the costs of searching for productive inputs. Moreover, the quality of specialized laborers and suppliers in the agglomeration is likely to be enhanced, as they make industry-specific investments in skills (Hanson, 2000). In emerging economies, such benefits are particularly likely because the capability gap between foreign and indigenous firms is typically wide, and local workers and suppliers primarily develop their skills by working with foreign entrants. Similarly, local managers with relevant experience in the industry and in international business, a scarce resource in emerging economies, may be recruited from other firms within the agglomeration (Mariotti \& Piscitello, 1995). Consistent with these theoretical arguments, empirical studies have found industry agglomeration to be conducive to innovation (Folta, Cooper \& Baik, 2006; Owen-Smith \& Powell, 2004), higher prices (Ghemawat \& Thomas, 2008) and productivity (Li, 2004).

However, industry co-location of FDI may also lead to higher costs. First, industry co-location increases competition for scarce resources. With an increasing number of foreign investors moving into the same location, competition for productive inputs, such as workers, land and utility services, intensifies (Folta et al., 2006), driving up the prices for these inputs (Head et 
al., 1995). Second, agglomeration may increase the risk of knowledge expropriation by foreign and domestic rivals located in the same area. Therefore, large and technologically advanced firms have been found to avoid co-locating with other firms in order to protect their technology (Chung \& Alcácer, 2002; Forman, Goldfarb \& Greenstein, 2008; Shaver \& Flyer, 2000).

\section{Country-of-Origin Agglomeration}

Country-of-origin agglomerations generate different kinds of inter-firm relationships and, therefore, different types of benefits than industry FDI agglomerations (Table 1). First, newcomers to a country often find it difficult to develop trust in local business partners because their lack of understanding of the local context increases their perceived vulnerability (Tsui-Auch \& Möllering, 2010). Inter-firm relationships within a country-of-origin agglomeration help developing such trust in several ways. First, ethnic ties and shared socio-cultural backgrounds facilitate the development of trust among compatriot FDI firms (Miller et al., 2008). People are more likely to have strong ties to those similar to themselves in terms of socially important attributes, such as ethnic origin (Manev \& Stevenson, 2001; Marsden, 1990). Second, compatriot firms face less uncertainty about each other because of their networks at home.

Table 1

Third, relationships among compatriots are supported by social interactions among expatriates. Compatriot FDI firms develop both formal networks such as country-based business associations and informal social networks such expatriates' personal and family involvement in the local expatriate community. For instance, expatriates often socialize with each other in activities such as sporting events and family activities (Tung, 1998). Not only do such social interactions provide important personal social support for the expatriates (Wang \& Kanungo, 
2004), but they also serve as a vital source of information about the host country environment (Feldman \& Bolino, 1999) and can create new business opportunities (Linehan, 2000).

Moreover, due to these structural differences, country-of-origin agglomeration and industry FDI agglomeration provide access to different types of local knowledge and resources. Entrants into an industry FDI agglomeration expect to benefit from the exchange of industry-specific knowledge and resources, whereas country agglomerations can help newcomers build their knowledge of the local context and reduce their liability of outsidership (Johanson \& Vahlne, 2009). Specifically, proximity to firms with the same country of origin facilitates learning about how to adapt to local environments and institutions because such knowledge is often culturally and institutionally sensitive. When moving abroad, firms have to transform routines they take for granted in their home environment to fit the host context (Cuervo-Cazurra et al., 2007). Foreign investors from the same socio-cultural backgrounds often have similar home business practices and are, therefore, likely to need similar processes to adapt to local environments (Liker, Fruin \& Adler, 1999). Thus, by interacting with compatriots, investors learn how to adapt to the local setting. At the same time, the local community also adapts to the presence of foreign investors, e.g., by learning relevant foreign languages (Chang \& Park, 2005). Investors may thus find local managers familiar with their home language and culture, as well as country-specific infrastructure such as schools, entertainment venues and food markets.

In addition, co-location by country of origin helps foreign investors to gain legitimacy in the host country environment in several ways. First, investors can take advantage of the "legitimacy spillover" generated by early entrants from the same country of origin (Kostova \& Zaheer, 1999:75). Second, they can learn from their compatriots how to respond effectively to legitimacy requirements. Cultural differences make it difficult for foreign entrants to achieve local 
legitimacy through isomorphism with indigenous firms. Therefore, foreign investors are forced to selectively adapt their business practices (Kostova, 1999). Sharing the same home business practices allows entrants to align with their compatriots and benefit from the local legitimacy those compatriots have already achieved. Third, foreign entrants can build on the legitimacy they enjoy back home because their track records reduce the uncertainty that potential business partners within their community of compatriots may have.

In an industry FDI agglomeration, inter-firm relationships are typically competitive or strategically cooperative, and are primarily built on contracts. They enable the sharing of knowledge that can be effectively protected by contracts, while other types of knowledge may be appropriated by industry competitors through reverse engineering, personnel movement and business intelligence (Bresman, Birkinshaw \& Nobel, 2010). Given this appropriation hazard, early foreign entrants may adopt various measures to prevent knowledge leakage and to reduce the likelihood of knowledge spillovers benefitting later entrants. This is less of a concern in country-of-origin agglomerations because they are less competitive, as firms may operate in different product markets and may not compete directly for inputs or customers. Even when they do compete, shared cultural backgrounds and languages facilitate coordination, thereby easing the intensity of competition and reducing knowledge-expropriation hazards. Consistent with these arguments, empirical studies show that co-location with ethnically similar FDI firms improves a foreign entrant's chance of survival (Miller et al., 2008).

Table 1 summarizes our comparison of industry FDI agglomeration and country-of-origin agglomeration. The two types of agglomeration differ in three major respects. First, the nature of inter-firm relationships is different between the two. Inter-firm relationships within an industry FDI agglomeration are competitive or cooperative (based on contracts), while inter-firm 
relationships within a country-of-origin agglomeration are supported by ethnic ties and exhibit a higher level of trust. Second, the two types of agglomeration provide access to different resources. Industry FDI agglomeration offers access to industry-specific knowledge and resources, while country-of-origin agglomeration provides access to general knowledge and support in the local environment. Third, the costs of agglomeration arising from competition for resources and expropriation hazards are less of a concern in country-of-origin agglomerations.

Both forms of FDI agglomeration are likely to be important, albeit in different ways. Before exploring the specific circumstances under which these types of agglomeration emerge, we offer two baseline propositions:

H1a: The higher the number of FDI firms within an industry in a location of an emerging economy, the greater the likelihood that foreign investors will enter.

H1b: The higher the number FDI firms with the same country of origin in a location of an emerging economy, the greater the likelihood that foreign investors will enter.

\section{Country-of-Origin vs. Industry FDI Agglomeration}

Our main question is: when do foreign investors co-locate with compatriots and when do they co-locate with foreign industry peers? Recent research on knowledge transfer between firms suggests that sensitive and tacit knowledge is best exchanged within relationships characterized by trust, shared cultures and embeddedness in shared networks (Adler \& Kwon, 2002; Dhanaraj, et al., 2004; Kostova, 1999; Lane, Salk \& Lyles, 2001; Szulanski, 1996). We extend this line of theorizing to suggest that such relationships are more likely to develop in country-of-origin agglomerations because they provide a stronger basis for building trust. Shared cultural backgrounds and languages cultivate trust among expatriates working in different firms within an agglomeration facilitates coordination and reduces uncertainty about business partners' actions, thereby promoting the sharing of sensitive and tacit local knowledge. In addition, a shared 
socio-cultural background improves an investor's absorptive capacity for tacit local knowledge (Lane \& Lubatkin, 1998; Parkhe, 1991). Country-of-origin agglomeration, therefore, acts as an important channel for accessing tacit local knowledge.

These benefits pertain particularly to investor firms that need knowledge about the specific local context in which they are investing. We identify such investors as: (1) those that perceive a high degree of institutional voids, and (2) those that experience a high degree of outsidership because of a lack of local experience or the absence of a local JV partner.

\section{In hostile territory, you need your friends the most}

Imperfections in the effectiveness of market exchange due to shortcomings in the institutional framework, known as institutional voids (Khanna \& Palepu, 2010), are a major concern in emerging economies. Institutional voids reduce the benefits of industry FDI agglomeration and make country-of-origin agglomeration more attractive.

In industry FDI agglomerations, inter-firm relationships are primarily based on contracts, which require effective contract enforcement. Institutional voids can undermine such relationships because firms cannot rely on the legal system as an efficient default option for the resolution of conflicts. In particular, lax enforcement of intellectual property rights may increase the risk of knowledge expropriation by competitors. Relational trust may compensate for this absence of a strong legal framework (Peng et al., 2008) but it is difficult for competitors to develop such trust.

In contrast, knowledge sharing within country-of-origin agglomeration is less inhibited by institutional voids because inter-firm relationships are built on trust and personal relationships. They rely less on formal contracts and thus require less support from legal institutions. In addition, compatriot FDI firms may have been involved in business relationships at home before 
entering the foreign market, which curbs potential opportunistic behavior. These conditions facilitate the exchange of sensitive or confidential information, such as information on methods of coping with instable institutions.

Institutional voids are particularly pertinent in emerging economies but their impact varies between and within countries. As an emerging economy is moving toward market liberalization, the pace of deregulation may vary among industry sectors. Furthermore, the implementation of legal reforms may vary across local magistrates and courts. Therefore, the extent of institutional voids faced by foreign investors within a host country varies with their exposure to specific local industries and law enforcement institutions. The more foreign investors experience obstacles with a local institutional framework, the higher their perceived uncertainty, and the lower their trust in publicly available information and in local business partners. This increases their need for local knowledge, networks and trustworthy sources of knowledge, and, consequently, their desire to tap into country-of-origin networks. Hence, we expect that firms perceiving greater institutional voids have a greater tendency to co-locate with other firms from the same country of origin.

H2: The greater the institutional voids perceived by foreign entrants, the more likely they will be to co-locate with other FDI firms of the same country origin rather than with other FDI firms in the same industry.

When you are an outsider, you need your friends the most

Co-locating with existing FDI firms provides one channel for foreign investors to access local knowledge - but it is not the only channel. A foreign entrant who can tap into local knowledge by other means will be less of an outsider in the local market and thus will rely less on FDI agglomeration as a source of local knowledge. This "outsidership" (Johanson and Vahlne, 2009) 
is likely to be higher for foreign investors that enter a foreign market for the first time and for those entering without a local partner. Such investors have a greater need for local knowledge and are thus more likely to locate in country-of-origin agglomerations.

Foreign entrants can learn about a local environment and develop know-how about doing business in a host market from their own prior experience in interacting with local workers, customers and suppliers (Johanson \& Vahlne, 1977). Furthermore, experienced investors have a better understanding of local complexities, which allows them to respond to institutional requirements more effectively and thus gain legitimacy (Kostova \& Zaheer, 1999). In contrast, first-time entrants experience a higher level of outsidership.

Some first-time entrants may reduce their outsidership by establishing in a joint venture with local partners (Anand \& Delios, 2002, Li \& Meyer, 2009; Meyer et al., 2009a). FDI firms that enter with local JV partners may gain access to their partners' suppliers and customers, and can also draw on their partners' knowledge of how to manage institutional voids and political risk. Working with local JV partners thus reduces the need to seek knowledge spillovers and institutional support from third parties.

On the other hand, first-time entrants with wholly owned investments experience a higher degree of outsidership in the local market. Potential local partners likely lack knowledge about their resources and capabilities, and are unsure about their trustworthiness and legitimacy. This knowledge gap makes it more difficult for these new entrants to attract business partners. They may, therefore, co-locate with compatriots to compensate for their lack of local knowledge, to build local legitimacy and to develop initial business relationships. In a compatriot network, first-timers will experience less outsidership because the shared culture and language - and possibly prior business relationships back home - help them to develop trust with other members 
in the network. Moreover, first-time entrants with wholly owned investments may rely on expatriates to a larger extent because they find it difficult to recruit in an unfamiliar local managerial labor market. In turn, country-of-origin agglomerations help expatriates, who are likely to be in the host country for the first time, to adapt professionally and personally to the local environment.

Foreign entrants with a high degree of outsidership may also benefit from co-locating with other FDI firms in the same industry (Table 1). However, these benefits are likely to be outweighed by those of co-locating with compatriots for several reasons. First, foreign entrants may gain more useful experiential knowledge from their compatriots than from their competitors because compatriots share similar structures (Lane \& Lubatkin, 1998) and have to go through similar processes of local adaptation. They may also develop higher levels of trust with their compatriots, which in turn help in the sharing of tacit knowledge (Luo \& Peng, 1999). Second, full ownership is often motivated by the aim to protect proprietary assets, such as technological knowledge, from unauthorized diffusion (Buckley \& Casson, 1976; Meyer et al., 2009b). If this is the case, then close interaction in an industry cluster may raise similar concerns. Hence, wholly owned investors may avoid industry FDI agglomeration but seek country-of-origin networks as the source of local knowledge. Therefore, we expect that:

H3: The higher the degree of outsidership experienced by foreign entrants (i.e., those without prior local experience and entering with wholly owned investments), the more likely they will be to co-locate with other FDI firms of the same country of origin than with other FDI firms in the same industry.

\section{Methodology}

We employ a conditional logit model to test our hypotheses (McFadden, 1974). This model estimates the probability that a foreign investor will choose a given region as a function of the 
attributes of that region, and has been widely used to examine location choice (e.g., Chang \& Park, 2005; Head et al., 1995, 1999; Head \& Ries, 1996; Shaver \& Flyer, 2000) .

We assume that a firm chooses to locate where it expects the highest profit, which is determined by the firm's demand and production functions. We define an underlying latent variable, $V_{i j}$, to represent the profit to firm $i$ of establishing a subsidiary in location $j$. The $\log$ linear form of profit function can be specified as:

$V_{i j}=\beta X_{i j}+\varepsilon_{i j}$

where $X$ is a vector of independent variables of theoretical interests (i.e., country and industry FDI agglomeration) and control variables (such as other location attributes that may affect location choice), and $\varepsilon$ is a random disturbance. The probability of a firm $i$ choosing location $j$ is $P_{i j}=\frac{\exp \left(\beta X_{i j}\right)}{\sum_{k=1}^{m} \exp \left(\beta X_{i k}\right)}$.

The function can be estimated using maximum likelihood techniques. A positive value for a coefficient $b$ indicates that the location with a higher value of the variable $x$ is more likely to be chosen. For instance, if $x$ is the number of FDI firms from the same country of origin, a positive value for its coefficient means that an increase in the number of FDI firms from the same country of origin in a location raises the probability of this location being chosen by a new foreign entrant from the same country of origin.; in other words, country-of-origin agglomeration influences location choice. Therefore, the sign and the significance of the coefficient reveal the presence or absence of a country-of-origin/industry agglomeration effect on location choice (Greene, 2003). ${ }^{3}$ However, $\beta$ cannot be interpreted as the marginal effect as in OLS

\footnotetext{
${ }^{3}$ We thank an anonymous reviewer for this insight.
} 
regressions. The marginal effects are $P_{j}\left(1-P_{j}\right) \beta$. In other words, the values of the marginal effects depend on the values of all other variables. One way to calculate the impact of the change in an explanatory variable (i.e., country and industry FDI agglomeration) is to set the other variables at theoretically interesting and empirically relevant values, such as means and medians (Hoetker, 2007; Long, 1997). A disadvantage of this approach is that, typically, very few observations would actually have the exact (means or medians) values. Train (1986) therefore suggests that it is more informative to calculate the average of the individual marginal effect at each observation. This is the approach that we adopt. We employ the margins command in STATA 11 to calculate the average marginal effect (at the original value of each observation).

Our main focus is on how firm and environmental characteristics influence the impact of agglomeration on location choice. In OLS regressions, such hypotheses are typically tested by entering interaction terms in the model. However, Ai and Norton (2003) show that such an approach creates interpretation difficulties in non-linear models, such as conditional logit models, because neither the estimated coefficients nor the marginal effects of interaction terms capture the signs and magnitudes of the interaction effects in these models. Therefore, we test these interaction effects by splitting the sample on the basis of firm and environmental characteristics, and then comparing the estimated coefficients for industry and country-of-origin FDI agglomeration in the subsample of theoretical interest (Hoetker, 2007). Another advantage of this approach is that it allows control variables to have different impacts on location choice in different subsamples (Shaver, 1998).

Sample

FDI in Vietnam provides an interesting empirical setting for our research question because Vietnam has distinct clusters of foreign investors from a wide range of industries and countries 
of origin. A critical decision for this sort of analysis is the choice of the geographic unit of analysis. Our theoretical arguments point to interpersonal relationships as the key mechanisms behind the hypothesized effects. The appropriate geographic unit of analysis would be therefore the space that individuals, such as expatriate managers, would move in their daily or weekly routine work. This suggests using a highly disaggregated unit of analysis. Vietnamese FDI data is disaggregated into 58 provinces, which provides an appropriate micro-structure for the geography of FDI. As we are interested in the set of locations that actually attract investors, we include only the 20 locations that the investors in our sample had entered. ${ }^{4}$

Our foreign investment data are taken from a survey that also formed the basis of a recent paper by Meyer and Nguyen (2005). However, we complement their data with additional data from archival sources, which eliminates the problem of common method variance. The survey, conducted in 2001, was administered as follows. The base population of the survey is all 2,454 FDI establishments that were set up between 1991 and 2000 with at least 10 employees and registered capital of at least US\$ 100,000 (source: the Ministry of Planning and Investment's database). A list of 900 firms was constructed through random sampling, of which 731 had useable contact information.

Meyer and Nguyen (2005) invested a great deal of effort in attaining high returns from all major business centres. The questionnaire was translated into Vietnamese and then translated back into English. Moreover, they prepared a Chinese translation using a similar procedure to target firms with Chinese origins, as these firms are known to be reluctant to complete questionnaires in English or Vietnamese. They also contacted most firms either face-to-face or by telephone. This process led to 171 completed questionnaires, representing $23.4 \%$ of the firms contacted. Of the 171 questionnaires, one had to be excluded because the firm was not an FDI as defined by OECD.

\footnotetext{
${ }^{4}$ We obtained consistent findings when we included the entire set of locations in the model estimation.
} 
Another 23 questionnaires were excluded because these FDI entries were full or partial acquisitions. $^{5}$ After comparing the base population and the sample, Meyer and Nguyen (2005) confirm that the sample is representative by all major criteria, including country of origin, industry, location within Vietnam, entry mode and registering authority in Vietnam (See Meyer and Nguyen (2005) for more details on the sample).

\section{Measures}

Our hypotheses concerns two sources of local knowledge spillovers: FDI firms from the same country-of-origin (same country FDI activity) and FDI firms in the same industry (same industry FDI activity). Same country FDI activity is proxied by the number of all subsidiaries previously established by firms of the same country of origin in a given province at the time of focal firm's entry. Same industry FDI activity is proxied by the number of all subsidiaries previously established by other foreign firms in the same industry in a given province at the time of the focal firm's entry. It should be noted that the two measures are based on the entire population of FDI firms rather than on just those in our sample. For a specific investor, an FDI firm in the same industry may also come from the same country of origin. To maintain mutual exclusivity in the two measures, we remove FDI firms that are both from the same country of origin and in the same industry (same country \& industry FDI activity) from the two measures. ${ }^{6}$

Our hypotheses identify several variables that may influence the impact of agglomeration

\footnotetext{
${ }^{5}$ In the case of acquisitions, location choice largely follows the location of the acquired firm, such that there is no "location decision" of the sort that is analyzed in this study. The proportion of acquisitions in the sample is small because legal constraints made them very difficult to implement before the time of the survey. The partial acquisitions in the sample were, in fact, established through the creation of a JV and the transfer of the local firms' operations to the new legal entity.

${ }^{6}$ For a given foreign entrant in our sample, the average number of same country \& industry FDI activity is 0.45 . This figure is relatively low compared to the average number of same country FDI activity (7.45) or to the average number of same industry FDI activity (1.87). Although the figure appears small, it is highly correlated with same country FDI activity $(\rho=0.68)$ and with same industry FDI activity $(\rho=0.52)$, indicating that factors leading to a foreign investor's choice to co-locate with compatriots or foreign industry peers also lead the investor to co-locate with FDI firms from the same industry and in the same industry if such a choice is available. As we are unable to disentangle the factors that lead to either country-of-origin agglomeration or industry FDI agglomeration, we leave the variable out of the estimation to avoid multicollinearity.
} 
on location choice. Perceived institutional void is measured using a ten-item scale $(\alpha=0.88)$ that assesses the extent to which the institutional environment was conducive to the subsidiary's business operations at the time of entry. ${ }^{7}$ Managers were asked to rate, on a five-point interval scale, the conduciveness of (1) procedures for obtaining business licenses, for purchasing real estate, for acquiring visa and work permits, and for meeting environmental regulations; (2) institutions and policies of local, provincial and central governments; and (3) the general legal framework and law enforcement. Managers were also asked whether they needed to make unofficial payments, and about the extent of stability and predictability of rules and regulations. The scales were reverse-coded when appropriate.

A foreign entrant's prior experience in Vietnam is a dummy variable with a value of one if the investor had commercial experience in Vietnam prior to the entry. As the existence or non-existence of local experience is the single most important factor in the building of local knowledge, this dummy provides an appropriate cut-off point for splitting the sample into two subsamples. Wholly owned investment is also a dummy variable taking the value of one if the investor owns at least $95 \%$ of the subsidiary's equity.

We include other FDI firm activity to control for any unspecified location factors that entice FDI firms to locate in a particular province. Other FDI firm activity is the number of existing foreign subsidiaries in a given province at the time of entry that are not from the same country of origin or in the same industry. In addition, as industry agglomeration benefits may also come from local industry peers, it would be ideal to include local industry firm activity as a control variable. Unfortunately, such data are not available to us. To proxy this effect, we include local firm activity to control for potential knowledge spillovers from local industry firms. Local firm

\footnotetext{
${ }^{7}$ An investor's perception may change several years after entry. To reduce memory bias, we explicitly asked respondents to rate the environment at two points in time (initial entry and current) and used only the value related to the initial entry for this study.
} 
activity is the number of local firms in a given province at the time of entry. ${ }^{8}$ Finally, to account for the possibility that other provincial differences affect location choice, we follow Head et al. (1995) and include alternative specific constants (i.e., location dummy variables) to capture provincial influences. These alternative-specific constants capture time-invariant location characteristics, such as geographic factors. We also follow Chung and Song (2004) to include province-specific time trends ${ }^{9}$ to capture time-variant, location-specific characteristics, such as economic and demographic indicators. In a further robustness check, we used the set of province-level control variables suggested by Meyer and Nguyen (2005), and arrive at results that are substantively similar to those reported in the Results section.

Table 2 presents the descriptive statistics and correlation coefficients for all variables except regional and time control variables. We take a logarithm transformation of the agglomeration variables because of their skewed distribution. This practice has been used in prior agglomeration studies (e.g., Chung and Song, 2004; Head et al., 1995).

\section{Results}

Table 3 shows the results of the conditional logit models. As discussed, the sign and significance of FDI activity coefficients provide insights into whether a particular agglomeration effect on location choice exists. A positive and significant coefficient indicates the existence of a particular agglomeration effect on location choice. The magnitude of the effect is captured by the average marginal effect, which indicates the impact of an increase in one percent of a particular type of

\footnotetext{
${ }^{8}$ We do not include firm-level control variables in the specification. As they do not vary across alternatives, their effects cannot be estimated using a conditional logit formulation (Shaver \& Flyer, 2000).

${ }^{9}$ Given the limited sample size, we use two-year intervals rather than one-year intervals. For instance, for the location, Hanoi, there are four Hanoi-specific time trends: Hanoi 93-94, Hanoi 95-96, Hanoi, 97-98 and Hanoi 99-00. We remove province-specific time trends in which there are no investors entering the province within the time interval.
} 
FDI activity on the probability of a location being chosen.

We enter the FDI activity variables incrementally. Model 1 includes only the regional dummies and province-specific time trends. Column 1 indicates that, collectively, these regional and time trend control variables are statistically significant. Model 2 adds other FDI activity and local firm activity. We expected other FDI activity to capture unspecified factors that attract foreign investors to locate in a particular province. Our empirical finding confirms that these unspecified factors influence foreign investors' location choices in Vietnam.

Model 3 adds the same country \& industry FDI activity variable explained in footnote 5. Column 3 indicates that this variable had a major influence on foreign investors' location choice in Vietnam $(\mathrm{p}<0.01)$. Conceptually, factors leading to a foreign investor's choice to co-locate with compatriots or foreign industry peers are likely to lead investors to co-locate with FDI firms from the same industry and in the same industry if such a choice is available. Therefore, it is not surprising that same country \& industry FDI activity is highly correlated with the two variables of interest in our study - same country FDI activity and same industry FDI activity. We remove it from the models onward in order to untangle individual effects of each type of FDI activity. While excluding this variable might overstate the significance of same country FDI activity and same industry FDI activity, such an issue creates less concern given that we examines the relative, rather than absolute, impact of the two types of FDI activities on location choice.

Model 4 adds same industry FDI activity (Hypothesis 1a) and Model 5 includes same country FDI activity (Hypothesis H1b). Both estimated coefficients are positive and significant at the 0.01 level, suggesting that both country-of-origin and industry FDI agglomerations exert influence on the location choice of foreign investors in Vietnam. This supports H1a and H1b. The magnitudes of the two effects, as reflected by the average marginal effects, suggest that the 
effect of same industry FDI activity is larger than that of same country FDI activity in the aggregate sample $(0.093>0.077)$.

Model 6 splits the full sample into two sub-samples based on the mean value of institution. ${ }^{10}$ We predict that managers who perceive greater institutional voids (Column 6a) are more likely to co-locate with compatriots than with foreign industry peers. The results show that both estimated coefficients of same country FDI activity and same industry FDI activity are positive and significant $(\mathrm{p}<0.01)$. The magnitude of same country FDI activity, as indicated by the average marginal effects, is indeed larger than that of same industry FDI activity $(0.033>0.024)$. Thus, $\mathrm{H} 2$ is supported. It is interesting to note that when institutional frameworks are well perceived, the location choices are different. The coefficient of same country FDI activity is not significant, while the coefficients of same industry FDI activity and other FDI activity are positive and significant $(\mathrm{p}<0.01)$. These findings suggest that better institutional frameworks promote transaction and knowledge transfer among FDI firms. When institutions are weak, trust plays an important role in facilitating transactions and information exchange. As foreign investors are more likely to trust their compatriots than their competitors, their tendency to co-locate with compatriots is greater.

Model 7 divides the sample by separating investors experiencing a higher level of outsidership (Column 7a) from other investors (Column 7b). H3 hypothesizes that location choices made by entrants experiencing a higher level of outsidership (i.e., firms in Column 7a) are influenced more by same country FDI activity country than by same industry FDI activity. The results show that both coefficients are positive and significant $(p<0.01)$. The magnitude of the same country FDI activity effect on location choice, as captured by average marginal effect, is larger than that of same industry FDI activity $(0.031>0.022)$. In contrast, for investors ${ }^{10}$ Splitting the sample based on the median value of institution yields identical results. 
experiencing a lower level of outsidership, only the coefficient of same industry FDI activity is significant $(\mathrm{p}<0.01)$ and it has a greater impact on location choice than same country FDI activity, as indicated by their comparative average marginal effects $(0.011<0.019)$. We therefore conclude that H3 is supported.

Although we expect foreign investors with a lower level of outsidership to already have access to local knowledge through their own experience or JV partners, our empirical results indicate that their location choice is still influenced by same industry FDI activity $(p<0.01)$. To further explore this result, we divide the sample firms into four groups based on their experience and entry modes: (1) inexperienced entrants with wholly owned investments, (2) inexperienced entrants with JVs, (3) experienced entrants with wholly owned investments, and (4) experienced entrants with JVs. We then ran the model separately for each group.

Table 4 presents the results. Column 1 corresponds to Model 7(a) in Table 3, and is repeated here to facilitate comparisons of the impact of FDI activity variables across different subgroups. Column 4 shows the results for investors who least need third-party local knowledge, as they have prior experience and local JV partners. As expected, none of the FDI activity variables are significant in this subgroup. The other two columns examine investors that have a moderate level of outsidership because they have some access to local market knowledge. For inexperienced investors who entered the market with JVs (Column 2), none of the coefficients for same country FDI activity or same industry FDI activity are significant at the 0.1 level. For experienced investors who make wholly owned investments (Column 3), coefficients of same country FDI activity and same industry FDI activity are both positive and significant (at the 0.05 and 0.01 levels, respectively), and the average marginal effect of the latter is larger $(0.045<0.055)$. This suggests that although these investors have access to local knowledge from their own prior 
experience, their location choice is still affected by both forms of FDI agglomeration, with industry FDI agglomeration being more important. As our study period covers the first decade after the Vietnamese market opened to FDI, even investors classified as experienced in our sample were unlikely to possess rich local experience. This might explain why these investors still find it important to locate in agglomerations to access local knowledge.

In terms of the control variables, the coefficients of other FDI activity are positive and significant in full sample models (Models 2-5). The coefficient of this variable is also positive and significant for investors who perceive better institutional frameworks $(\mathrm{p}<0.01)$ and for those who experience a higher level of outsidership $(\mathrm{p}<0.05)$. This suggests that, in addition to compatriots and foreign industry competitors, these investors seek local knowledge spillovers from FDI firms that are from different countries of origin and different industries. The coefficients of local firm activity are generally insignificant, suggesting that investors generally do not source local knowledge from local firms. It is interesting to note that this coefficient is negative in Column 7a of Table 3, indicating that entrants experiencing a high level of outsidership in Vietnam tend to avoid locating near local firms.

Finally, we examine whether our data meet the assumption of independence of irrelevant alternatives (IIA) - an assumption underlying the conditional logic model. This assumption implies that the probability of choosing one location over another is independent of the availability of other locations. We performed a Hausman and McFadden (1984) test to check the validity of the assumption. The test is based on the idea that if a subset of the location choice set is irrelevant, its omission from the model will not systematically change the estimates. We ran the test by excluding each location from the choice set. The results show that our model meets the IIA assumption. 


\section{Discussion}

We have examined how foreign investors seek local knowledge in an emerging economy, i.e., Vietnam, through location choices. Our findings confirm that foreign investors tend to co-locate with other FDI firms of the same country of origin and with those in the same industry. However, we move beyond earlier studies by exploring when the two types of agglomeration are especially relevant. Our theoretical arguments suggest that country-of-origin agglomeration is particularly relevant for investors who perceive extensive institutional voids and those who lack local knowledge.

First, we find that institutional voids weaken the impact of industry FDI agglomeration on location choice. Weak institutions give rise to transaction hazards among strangers and competitors. Thus, although a foreign entrant located in the industry cluster might gain access to a greater pool of suppliers and customers, any transactional relationship with the suppliers and customers may be poorly protected. Lack of effective intellectual property rights enforcement may also increase the entrant's risk of knowledge being expropriated. This would result in strategic behavior among incumbents to prevent information and knowledge disclosure, which would reduce the likelihood that the new entrant will benefit from information spillovers. In contrast, institutional voids increase the benefits of country agglomeration. When institutions are weak, trust and personal relationships become more important for accessing knowledge. New entrants can locate near their compatriots, and use their common cultural background and language as a basis for the development of trust, after which they can build their local transaction network and gain access to knowledge spillovers.

Second, our empirical results indicate that a firm's location choice is interdependent with its 
market entry mode and its local experience. First-time foreign investors that enter Vietnam with wholly owned investments tend to co-locate with compatriots and foreign industry peers, while those entering Vietnam through joint ventures, either with or without prior experience, do not have such a preference. Hence, different aspects of entry strategies can supplement each other as means of accessing local knowledge.

Our paper contributes to several lines of literature. First, this paper adds to the growing understanding of country-of-origin agglomeration (e.g., Chang and Park, 2005; Miller et al., 2008), which is an important aspect of the location decisions made by multinational firms (Dunning, 1998). Previous related research has mostly focused on industry FDI agglomeration. We examine both forms of FDI agglomeration simultaneously and, to our knowledge, are the first to compare the magnitudes of the two agglomeration effects. We demonstrate how country-of-origin agglomeration differs from industry FDI agglomeration as a source of local knowledge. In so doing, we identify the types of institutional environments in which the country-of-origin agglomeration effects are likely to be strong. This enhances our understanding of how foreign investors' perceptions of institutions affect international business strategy (Peng et al., 2008; Meyer et al., 2009a; Tsui-Auch \& Möllering, 2010).

Second, we extend the debate on one of the key concepts in international business research, the liability of foreignness (Hymer, 1968; Zaheer, 2005). In particular, we respond to Johanson and Vahlne's (2009) call to move from "liability of foreignness" to "liability of outsidership" as the focal concept in international business theorizing. In other words, it is not foreignness per se that matters for international business strategies, as there are various degrees to which a newcomer is an outsider in a specific local community. In this regard, we demonstrate that country-of-origin agglomeration is a way for newcomers to build local knowledge and reduce the 
liability of being an outsider.

Third, we contribute to the study of foreign entry strategies by explaining the interdependence of different aspects of entry strategies - location and mode choice (McCann \& Folta, 2008; Meyer et al., 2009b). We argue that the building of local knowledge in an organization is a pivotal aim that drives the design of entry strategies. From this perspective, experience, location and mode choice offer alternative means to the same objective.

For our empirical study, we have chosen an emerging economy context, which allows us to contribute to the burgeoning amount of literature based on empirical data from emerging economies (Meyer \& Peng, 2005). However, while our basic arguments primarily apply to emerging economies where institutions are weak and networks are important, we believe that they may also be applicable to developed economies facing some of these institutional obstacles. In this regard, future research may explore the generalizability of the findings to other contexts.

In terms of methodology, future studies may employ more detailed controls for the presence of local firms, especially when investigating contexts in which local firms are technologically closer to the leading-edge technologies likely to be employed by foreign investors. Furthermore, this study focuses on country-of-origin agglomeration effects. Yet, MNEs from culturally similar countries may also find it easier to develop trust than MNEs from culturally distant countries (Miller et al., 2008). Future studies could examine whether and when MNEs are more likely to co-locate with other firms from different but similar national cultures. Finally, our paper focuses on how the characteristics and entry strategies of foreign investors influence their choice to co-locate with either compatriots or with foreign industry competitors. Future studies can explore how the co-location choice may be affected by other factors, such as knowledge characteristics.

For business practitioners, co-locating with foreign industry peers may provide access to 
industry-specific local knowledge and resources. However, if their primary concern is uncertainty due to weak institutions, then co-locating with compatriots may provide access to knowledge on how best to interact with the local context. For policymakers eager to attract foreign investors, improvements in the institutional framework may be the best choice. As such improvements may be difficult to implement, governments may facilitate country-of-origin agglomerations to attract investors who are unfamiliar with the local context.

\section{Conclusion}

This study investigates the determinants of FDI agglomeration, and distinguishes between co-location with foreign investors in the same industry and co-location with foreign investors with the same country of origin. We explore the nature of knowledge transfers facilitated by either form of agglomeration, and argue that country of origin agglomeration is particularly conducive for gaining access to tacit knowledge on how the local economy functions - which is, in particular, of interest to foreign investors in emerging economies. We find that co-location by country of location is used more by investors who are in need of such knowledge because they are either still outsiders to the local context or because they perceive the local institutions as difficult to handle. These results are expected to provide stimuli for future research on international business strategies, most notably the concepts of co-location, liability of outsidership and foreign entry strategies. 


\section{References}

Ai, C. \& Norton, E.C. 2003. Interaction terms in logit and probit models. Economics Letters, 80: 123-129.

Adler, P. \& Kwon, S.W. 2002. Social capital: prospects for a new concept. Academy of Management Review, 27: 17-40.

Almeida P. \& Kogut, B. 1997. The exploration of technological diversity and the geographic localization of innovation. Small Business Economics, 9:21-31.

Anand, J., \& Delios, A. 2002. Absolute and relative resources as determinants of international acquisitions. Strategic Management Journal, 23: 119-134.

Bresman, H., Birkinshaw, J. \& Nobel, R. 2010. Knowledge transfer in international acquisitions. Journal of International Business Studies, 41(1): 5-20.

Buckley, P. J., \& Casson, M. C. 1976. The future of the multinational enterprise, London: Macmillan.

Chang, S-J. \& Park, S. 2005. Types of firms generating network externalities and MNCs' co-location decisions. Strategic Management Journal, 26: 595-615.

Chung, W. \& Alcácer, J. 2002. Knowledge seeking and location choice of foreign direct investment in the United States. Management Science, 48(12): 1534-1554.

Chung, W. \& Song, J. 2004. Sequential investment, firm motives, and agglomeration of Japanese electronics firms in the United States. Journal of Economics \& Management Strategy: 13(3): 539-560.

Cuervo-Cazurra, A., Maloney, M.M. \& Manrakhan, S. 2007. Causes of the difficulties in internationalization. Journal of International Business Studies, 38: 709-725.

Dhanaraj, C., Lyles, M.A., Steema, H.K. \& Tihanyi, L. 2004. Managing tacit and explicit knowledge transfer in IJVs: the role of relational embeddedness and the impact on performance. Journal of International Business Studies, 35: 428-442.

Dunning J. H. 1998. Location and the multinational enterprise: A neglected factor? Journal of International Business Studies, 29(1): 45-66.

Feldman, D. \& Bolino, M. 1999. The impact of on-site mentoring on expatriate socialization. International Journal of Human Resource Management, 10: 54-71.

Filatotchev, I., Strange, R., Piesse, J. \& Lien, Y.-C. 2007. FDI by firms from newly industrialized economies in emerging markets: corporate governance, entry mode and location. Journal of 
International Business Studies, 38: 556-572.

Folta, T. B., Cooper, A. C., \& Baik, Y.-S. 2006. Geographical cluster size and firm performance. Journal of Business Venturing, 21: 217-242.

Forman, C., Goldfarb, A. \& Greenstein, S. 2008. Understanding the inputs into innovation: Do cities substitute for internal firm resources? Journal of Economics and Management Strategy, 17(2): 295-316.

Ghemawat, P. \& Thomas, C. 2008. Strategic interaction across countries and multinational agglomeration: An application to the cement industry. Management Science, 54(12): 1980-1996.

Greene, W. H. 2003. Econometric Analysis. New York, NY: Macmillan.

Hanson, G. 2000. Firms, workers, and the geographic concentration of economic activity. In Clark, G. L., Feldman, M. P. \& Gertler, M. S. (Eds.), The Oxford Handbook of Economic Geography: 477-494. NY: New York.

Hansen, M. T. 1999. The search-transfer problem: the role of weak ties in sharing knowledge across organizational subunits. Administrative Science Quarterly, 44: 82-111.

Hansen, M. T. \& Løvas, B. 2004. How do multinational companies leverage technological competencies? Moving from single to interdependent explanations. Strategic Management Journal, 25: 801-822.

Hausman, J. \& McFadden, D. 1984. Specification tests for the multinomial logit model. Econometrica, 52(5): 1219-1240.

Head, K. \& Ries, J. 1996. Inter-city competition for foreign investment: Static and dynamic Effects of China's Incentive Areas. Journal of Urban Economics, 40(1): 38-60.

Head, K., Ries, J. \& Swenson, D. 1995. Agglomeration benefits and location choice: Evidence from Japanese manufacturing investments in the United States. Journal of International Economics, 38(3-4): 223-247.

Head, K., Ries, J. \& Swenson, D. 1999. Attracting foreign manufacturing: Investment promotion and agglomeration. Regional Science and Urban Studies, 29(2):197-216.

Hoetker, G. 2007. The use of logit and probit models. Strategic Management Journal, 28: $331-343$

Hymer, S. H. 1968. The large multinational "corporation". In M. Casson (Ed.) Multinational Corporations: 6-31. London: Edward Elgar. 
Johanson, J. \& Vahlne, J.-E. 1977. The internationalization process of the firm - A model of knowledge development and increasing foreign market commitments. Journal of International Business Studies, 8: 23-32.

Johanson, J. \& Vahlne, J.-E. 2009. The Uppsala internationalization model revisited: From liability of foreignness to liability of outsidership, Journal of International Business Studies, 40(9): 1411-1431.

Khanna, T. \& Palepu, K. 2010. Winning in emerging markets, Cambridge, MA: Harvard Business School Press.

Kostova, T. 1999. Transnational transfer of strategic organizational practices: a contextual perspective. Academy of Management Review, 24(2): 308-324.

Kostova, T. \& Zaheer, S. 1999. Organizational legitimacy under conditions of complexity: The case of the multinational enterprise. Academy of Management Review, 24(1): 64-81.

Krugman, P. 1991. Increasing returns and economic geography. Journal of Political Economy, 99(3): 483-499.

Lane, P. J. \& Lubatkin, M. 1998. Relative absorptive capacity and interorganizational learning. Strategic Management Journal, 19(5): 461-478.

Lane, P.J., Salk, J.E., \& Lyles, M.A. 2001. Absorptive capacity, learning, and performance in international joint ventures. Strategic Management Journal, 22: 1139-1161.

Li, P.-Y. \& Meyer, K. E. 2009. Contextualizing experience effects in international business: A study of ownership strategies. Journal of World Business, 44 (4): 370-382.

Li, S. 2004. Location and performance of foreign firms in China. Management International Review, 44(2): 151-169.

Liker, J., Fruin, M., Adler, P. S. 1999. Bringing Japanese Management Systems to the U.S.: Transplantation or Transformation? In Liker, J., Fruin, M., Adler, P. (Ed.), Remade in America: Transplanting and transforming Japanese management systems. New York, NY: Cambridge University Press: 3-38.

Linehan, M. 2000. Senior Female International Managers: Why So Few? Burlington, VT: Ashgate Publishing.

Long, J. S. 1997. Regression Models for Categorical and Limited Dependent Variables. Thousand Oaks, CA: Sage.

Lord, M. D. \& Ranft, A. L. 2000. Organizational learning about new international markets: 
exploring the internal transfer of local market knowledge. Journal of International Business Studies, 31(4): 573-589.

Luo, Y. \& Peng, M. W. 1999. Learning to compete in a transition economy: experience, environment, and performance, Journal of International Business Studies, 30(2): 269-296.

Manev, I. M. \& Stevenson, W. B. 2001. Nationality, cultural distance and expatriate status: Effects on the managerial network in a multinational enterprise. Journal of International Business Studies, 32(2): 285-303.

Mariotti, S. \& Piscitello, L. 1995. Information costs and location of FDIs within the host country: Empirical evidence from Italy. Journal of International Business Studies, 26(4): 815.

Marsden, P. 1990. Network data and measurement. Annual Review of Sociology, 16: 435-463.

Marshall, A. 1920. Principles of Economics. 8th ed, London: Macmillan.

McCann, B. T. \& Folta, T.B. 2008. Location matters: Where we have been and where we might go in agglomeration research. Journal of Management, 34(3): 532-565.

McFadden, D. 1974. Conditional logit analysis of qualitative choice behavior. In Frontier in Econometrics, Zarembka, P. (ed). New York: Academic Press, 105-142.

Meyer, K. E.; Estrin, S., Bhaumik, S. K. \& Peng, M. W. 2009a. Institutions, resources, and entry strategies in emerging economies, Strategic Management Journal, 30 (1): 61-80.

Meyer K. E. \& Nguyen, H. V. 2005. Foreign investment strategies and sub-national institutions in Emerging Markets: Evidence from Vietnam, Journal of Management Studies 42: 63-93.

Meyer, K. E. \& Peng, M. W. 2005. Probing theoretically into central and eastern Europe: transactions, resources and institutions. Journal of International Business Studies, 36 (6): 600-621.

Meyer, K. E., Wright M. \& Pruthi, S. 2009b. Managing knowledge in foreign entry strategies: A resource-based analysis, Strategic Management Journal, 30(5): 557-574.

Miller, S. R., Thomas, D. E., Eden, L. \& Hitt, M. 2008. Knee deep in the big muddy: The survival of emerging market firms in developed markets. Management International Review, 48(6): 645-665.

Mitchell, W., Shaver, J. M. \& Yeung, B. 1994. Foreign entrant survival and foreign market share: Canadian companies' experience in the United States medical sector markets. Strategic Management Journal, 15(7): 555-567.

Nachum L. \& Wymbs, C. 2005. Product differentiation, external economies and MNE location 
Choices: M\&As in global cities. Journal of International Business Studies, 36(4): 415-434.

Owen-Smith, J. \& Powell, W. W. 2004. Knowledge networks as channels and conduits: The effects of spillovers in the Boston biotechnology community. Organization Science, 15(1): $5-21$.

Parkhe, A. 1991. Interfirm diversify, organizational learning and longevity in global strategic alliances. Journal of International Business Studies, 22: 579-602.

Peng M. W., Wang D. \& Jiang Y. 2008. An institution-based view of international business strategy: a focus on emerging economies. Journal of International Business Studies 39(5): 920-936

Pérez-Nordtvedt, L., Kedia, B. L., Datta, D. K., \& Rasheed, A.A. 2008. Effectiveness and efficiency of cross-border knowledge transfer: An empirical examination. Journal of Management Studies, 45(4): 714-744.

Polanyi, M. 1962. Personal Knowledge, Chicago, IL: University of Chicago Press.

Porter, M. E. 1998. Clusters and the new economics of competition. Harvard Business Review, 76(6): 77-90.

Pouder, R. \& St. John, C. H. 1996. Hot spots and blind spots: Geographical clusters of firms and innovation. Academy of Management Journal, 21(4): 1192-1225.

Saxenian, A. 1994. Regional Advantage. Cambridge, MA: Harvard University Press.

Shaver, J.M. 1998. Accounting for endogeneity when assessing strategy performance: Does entry mode choice affect FDI survival? Management Science, 44(4): 571-585.

Shaver, J. M. \& Flyer, F. 2000. Agglomeration economies, firm heterogeneity, and foreign direct investment in the United States. Strategic Management Journal, 21(12): 1175-1193.

Shaver, J. M., Mitchell, W. \& Yueng, B. 1997. The effect of own-firm and other-firm experience on foreign direct investment survival in the United States, 1987-92. Strategic Management Journal, 18: 811-824.

Steensma, K. \& Lyles, M. A. 2000. Explaining IJV survival in a transitional economy through social exchange and knowledge-based perspectives. Strategic Management Journal, 21(8): 831-852.

Strange, R., Filatotchev, I., Lien, Y., Piesse, J. 2009. Insider control and the FDI location decision: Evidence from firms investing in an emerging markets. Management International Review, 49: 433-454. 
Szulanski, G. 1996. Exploring internal stickiness: impediments to the transfer of best practice within the firm. Strategic Management Journal, 17 (special issue): 27-43.

Train, K. 1986. Qualitative Choice Analysis: Theory, Econometrics, and an Application to Automobile Demand. Cambridge, MA: MIT Press.

Tsui-Auch, L.S. \& Möllering, G. 2010. Wary managers: Unfavorable environments, perceived vulnerability, and the development of trust in foreign enterprises in China, Journal of International Business Studies 41(6): 1016-1035.

Tung, R. L. 1998. American expatriates abroad from Neophytes to cosmopolitans. Journal of World Business, 33: 125-144.

Wang, X. \& Kanungo, R. N. 2004. Nationality, social network, and psychological well-being: expatriates in China. International Journal of Human Resource Management, 15(4): 775-793.

Wei, Y., Liu X., Parker D. \& Vaidya, K. 1999. The regional distribution of foreign direct investment in China. Regional Studies, 33(9): 857-867.

Wright, M., Filatotchev, I., Hoskisson, R. E., \& Peng, M. W. 2005. Strategy research in emerging economies: Challenging the conventional wisdom. Journal of Management Studies, 42(1): $1-33$.

Zaheer, S. 1995. Overcoming the liability of foreignness. Academy of Management Journal, 38(2): 341-363. 
Table 1 Comparison of Industry and Country-of-Origin FDI Agglomeration

\begin{tabular}{|c|c|c|}
\hline & Industry FDI agglomeration & Country-of-origin agglomeration \\
\hline $\begin{array}{l}\text { Inter-firm } \\
\text { relationships }\end{array}$ & $\begin{array}{ll}\text { - } & \text { Often in direct competition } \\
\text { - } & \text { Contractual-based cooperation }\end{array}$ & $\begin{array}{l}\text { - Normally not in direct competition } \\
\text { - Benefit from a higher level of trust }\end{array}$ \\
\hline Benefits & $\begin{array}{l}\text { Access to local, industry-specific } \\
\text { knowledge } \\
\text { Access to local, industry-specific } \\
\text { resources (such as specialized } \\
\text { labor/inputs, partners, customers } \\
\text { and infrastructure) }\end{array}$ & $\begin{array}{l}\text { - Access to local market knowledge } \\
\text { - Access to local, } \\
\text { home-country-specific resources } \\
\text { - Easier to gain legitimacy }\end{array}$ \\
\hline Costs & $\begin{array}{l}\text { - Competition for scarce resources } \\
\text { - Knowledge expropriation hazards }\end{array}$ & $\begin{array}{l}\text { - Less-intensive resource competition } \\
\text { - Fewer knowledge expropriation } \\
\text { hazards }\end{array}$ \\
\hline
\end{tabular}


Table 2 Descriptive Statistics and Correlation Matrix

\begin{tabular}{|c|c|c|c|c|c|c|c|c|c|c|c|}
\hline Variable & Mean & Std. Dev. & Min & Max & 1 & 2 & 3 & 4 & 5 & 6 & 7 \\
\hline 1. Same country FDI activity & 7.45 & 22.26 & 0 & 205 & & & & & & & \\
\hline 2. Same industry FDI activity & 1.87 & 5.77 & 0 & 81 & $0.45^{*}$ & & & & & & \\
\hline $\begin{array}{l}\text { 3. Same country \& industry } \\
\text { FDI activity }\end{array}$ & 0.45 & 1.82 & 0 & 29 & $0.68 *$ & $0.52 *$ & & & & & \\
\hline 4. Other FDI activity & 48.59 & 106.28 & 0 & 802 & $0.69 *$ & $0.66^{*}$ & $0.51^{*}$ & & & & \\
\hline 5. Local firm activity & 15795.92 & 16993.19 & 2300 & 69501 & 0.01 & 0.03 & 0.02 & $0.04 *$ & & & \\
\hline 6. Institution & 3.08 & 0.66 & 1.2 & 5 & $0.12 *$ & 0.00 & $0.07 *$ & $0.05^{*}$ & -0.01 & & \\
\hline 7. Prior local experience & 0.31 & 0.46 & 0 & 1 & 0.01 & 0.03 & -0.01 & 0.02 & 0.00 & -0.01 & \\
\hline 8. Wholly owned investment & 0.63 & 0.49 & 0 & 1 & $0.11 *$ & $0.04 *$ & $0.06^{*}$ & $0.09 *$ & -0.01 & 0.13 & $-0.18^{*}$ \\
\hline
\end{tabular}

$\mathrm{N}=2,940 * \mathrm{p}<0.05$ 
Table 3 Conditional Logit Regression Results of Location Choice

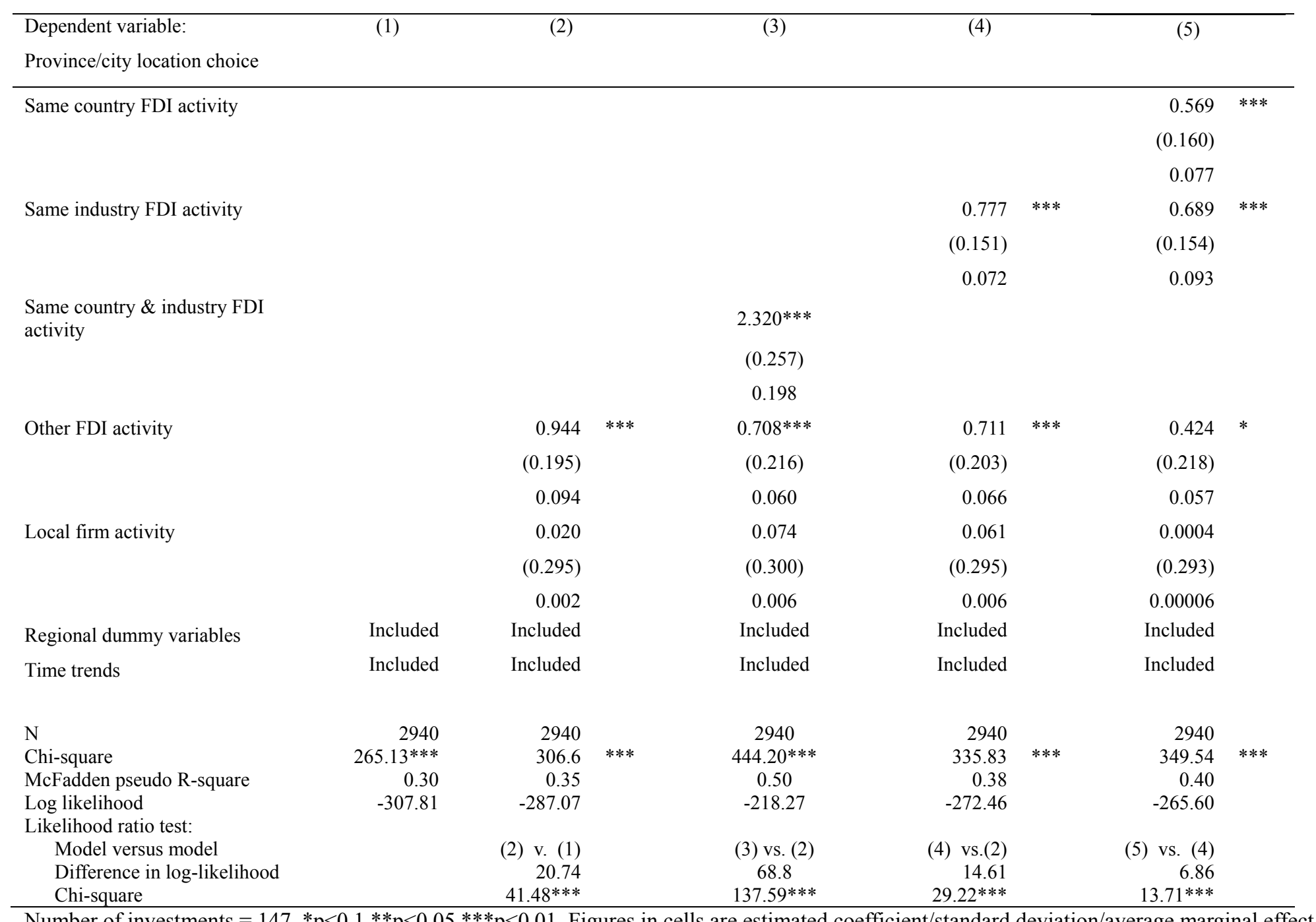

p $<0.01$. Figures in cells are estimated coefficient/standard deviation/average marginal effect.

McFadden's R-square $=1-[(\log$ likelihood of the fitted model $) /(\log$ likelihood of the null model $)]$ 
Table 3 Conditional Logit Regression Results of Location Choice (Continued)

\begin{tabular}{|c|c|c|c|c|c|c|c|c|}
\hline \multirow{3}{*}{$\begin{array}{l}\text { Dependent variable: } \\
\text { Province/city location choice }\end{array}$} & \multicolumn{4}{|l|}{ (6) } & \multicolumn{4}{|l|}{ (7) } \\
\hline & \multicolumn{2}{|c|}{ Poor institution } & \multicolumn{2}{|c|}{ Good institution } & \multicolumn{2}{|c|}{$\begin{array}{l}\text { Entrants with a higher degree } \\
\text { of outsidership }\end{array}$} & \multicolumn{2}{|c|}{$\begin{array}{l}\text { Entrants with a lower degree } \\
\text { of outsidership }\end{array}$} \\
\hline & Coefficient & & Coefficient & & Coefficient & & Coefficient & \\
\hline Same country FDI activity & $\begin{array}{r}0.754 \\
(0.236) \\
0.033\end{array}$ & $* * *$ & $\begin{array}{r}0.320 \\
(0.218) \\
0.004\end{array}$ & & $\begin{array}{r}0.883 \\
(0.290) \\
0.031\end{array}$ & $* * *$ & $\begin{array}{r}0.315 \\
(0.213) \\
0.011\end{array}$ & \\
\hline Same industry FDI activity & $\begin{array}{r}0.543 \\
(0.210) \\
0.024\end{array}$ & $* * *$ & $\begin{array}{r}0.918 \\
(0.250) \\
0.010\end{array}$ & $* * *$ & $\begin{array}{r}0.647 \\
(0.251) \\
0.022\end{array}$ & $* * *$ & $\begin{array}{r}0.567 \\
(0.201) \\
0.019\end{array}$ & $* * *$ \\
\hline Other FDI activity & $\begin{array}{r}-0.189 \\
(0.360) \\
-0.008\end{array}$ & & $\begin{array}{r}0.786 \\
(0.296) \\
0.009\end{array}$ & $* * *$ & $\begin{array}{r}1.103 \\
(0.501) \\
0.038\end{array}$ & $* *$ & $\begin{array}{r}-0.320 \\
(0.353) \\
-0.011\end{array}$ & \\
\hline Local firm activity & $\begin{array}{r}-0.466 \\
(0.495) \\
-0.020\end{array}$ & & $\begin{array}{r}0.262 \\
(0.382) \\
0.003\end{array}$ & & $\begin{array}{r}-1.143 \\
(0.358) \\
-0.040\end{array}$ & $* * *$ & $\begin{array}{r}-0.418 \\
(0.437) \\
-0.014\end{array}$ & \\
\hline $\begin{array}{l}\text { Regional dummy control } \\
\text { Time trends }\end{array}$ & $\begin{array}{l}\text { included } \\
\text { included }\end{array}$ & & $\begin{array}{l}\text { included } \\
\text { included }\end{array}$ & & $\begin{array}{l}\text { included } \\
\text { included }\end{array}$ & & $\begin{array}{l}\text { included } \\
\text { included }\end{array}$ & \\
\hline $\begin{array}{l}\mathrm{N} \\
\text { No of investments } \\
\text { Chi-square } \\
\text { McFadden pseudo R-square } \\
\text { Log likelihood }\end{array}$ & $\begin{array}{r}1520 \\
76 \\
179.23 \\
0.39 \\
-138.06 \\
\end{array}$ & $* * *$ & $\begin{array}{r}1420 \\
71 \\
191.52 \\
0.45 \\
-116.94 \\
\end{array}$ & $* * *$ & $\begin{array}{r}1340 \\
67 \\
221.9 \\
0.55 \\
-89.76 \\
\end{array}$ & $* * *$ & $\begin{array}{r}1500 \\
75 \\
165.84 \\
0.37 \\
-141.76 \\
\end{array}$ & $* * *$ \\
\hline
\end{tabular}


Table 4 Comparison of Same Country FDI Activity and Same Industry FDI Activity Based on Prior Experience and Mode of Entry

(1)

(4)

\begin{tabular}{|c|c|c|c|c|c|c|}
\hline \multirow{3}{*}{$\begin{array}{l}\text { Dependent variable: } \\
\text { Province/city location } \\
\text { choice } \\
\text { Same country FDI activity }\end{array}$} & \multirow{2}{*}{\multicolumn{2}{|c|}{$\begin{array}{c}\text { Inexperienced entrants with } \\
\text { wholly owned investments } \\
\text { Coefficient }\end{array}$}} & \multirow{3}{*}{$\begin{array}{c}\text { Inexperienced entrants with } \\
\text { JVs } \\
\text { Coefficient } \\
\\
0.073 \\
(0.343) \\
0.002\end{array}$} & \multirow{2}{*}{\multicolumn{2}{|c|}{$\begin{array}{c}\text { Experienced entrants with } \\
\text { wholly owned investments } \\
\text { Coefficient }\end{array}$}} & \multirow{3}{*}{$\begin{array}{c}\begin{array}{c}\text { Experienced entrants } \\
\text { with JVs }\end{array} \\
\text { Coefficient } \\
\\
0.032 \\
(0.431) \\
0.0002\end{array}$} \\
\hline & & & & & & \\
\hline & $\begin{array}{r}0.883 \\
(0.290) \\
0.031\end{array}$ & $* * *$ & & $\begin{array}{r}1.212 \\
(0.551) \\
0.045\end{array}$ & $* *$ & \\
\hline Same industry FDI activity & $\begin{array}{r}0.647 \\
(0.251) \\
0.022\end{array}$ & $* * *$ & $\begin{array}{c}0.533 \\
(0.336) \\
0.012\end{array}$ & $\begin{array}{r}1.488 \\
(0.491) \\
0.055\end{array}$ & $* * *$ & $\begin{array}{c}0.035 \\
(0.324) \\
0.0002\end{array}$ \\
\hline Other FDI activity & $\begin{array}{r}1.103 \\
(0.501) \\
0.038\end{array}$ & $* *$ & $\begin{array}{c}0.614 * * \\
(0.289) \\
0.014\end{array}$ & $\begin{array}{r}-0.213 \\
(0.852) \\
-0.008\end{array}$ & & $\begin{array}{l}-0.936 \\
(0.773) \\
-0.005\end{array}$ \\
\hline Local firm activity & $\begin{array}{r}-1.143 \\
(0.358) \\
-0.040\end{array}$ & $* * *$ & $\begin{array}{c}0.202 \\
(0.340) \\
0.005\end{array}$ & $\begin{array}{r}-0.673 \\
(1.628) \\
-0.025\end{array}$ & & $\begin{array}{l}-0.503 \\
(0.748) \\
-0.003\end{array}$ \\
\hline $\begin{array}{l}\text { Regional dummy control } \\
\text { Time trends }\end{array}$ & $\begin{array}{l}\text { included } \\
\text { included }\end{array}$ & & $\begin{array}{l}\text { included } \\
\text { included }\end{array}$ & $\begin{array}{l}\text { included } \\
\text { included }\end{array}$ & & $\begin{array}{l}\text { included } \\
\text { included }\end{array}$ \\
\hline $\begin{array}{l}\mathrm{N} \\
\text { No of investments } \\
\text { Chi-square } \\
\text { McFadden pseudo R-square } \\
\text { Log likelihood }\end{array}$ & $\begin{array}{r}1340 \\
67 \\
221.9 \\
0.55 \\
-89.76\end{array}$ & $* * *$ & $\begin{array}{c}620 \\
31 \\
77.13^{* * * *} \\
0.42 \\
-54.30\end{array}$ & $\begin{array}{r}440 \\
22 \\
78.59 \\
0.60 \\
-26.61\end{array}$ & $* * *$ & $\begin{array}{c}440 \\
22 \\
41.17 * * * \\
0.31 \\
-45.32\end{array}$ \\
\hline
\end{tabular}

$* \mathrm{p}<0.1 * * \mathrm{p}<0.05 * * * \mathrm{p}<0.01$. Figures in cells are estimated coefficient/standard deviation/average marginal effect. 